\title{
KREACJA W UBIORZE JAKO ELEMENT TWÓRCZEJ EKSPRESJI I KOMUNIKACJI ARTEFAKTYCZNEJ W KONTEKŚCIE ZACHODZĄCYCH ZMIAN W ESTETYCE WYGLACDU KOBIETY. NA PODSTAWIE AUTORSKICH DOŚWIADCZEŃ I DOKONAŃ ARTYSTYCZNO-DYDAKTYCZNYCH
}

\author{
MONIKA KOSTRZEWA
}

Poniższy tekst dotyczył będzie zagadnień związanych z ubiorem jako elementem twórczych działań zmierzających do wyrażania ekspresji osobowości i wizualnego obrazu kobiety. Dotyczyć będą również procesu kreowania formy ubioru ważnego składnika komunikacji artefaktycznej wpływającego na percepcję naszej codzienności i niecodzienności. Rozważania oparte będą na wybranych zagadnieniach z zakresu własnej twórczości i badaniach nad wyglądem kobiety w procesie zachodzących zmian w kulturze ubioru i estetyce tworzenia wizerunku. Własne przemyślenia zmierzające do podkreślenia znaczenia i roli ubioru jako jednej z form wyartykułowania własnej ekspresji skoncentruję głownie na kobiecie, do której kieruję większość moich ostatnich kolekcji.

Szczególną uwagę w tekście poświęcę na to, w jaki sposób ubiór będący w bezpośrednim kontakcie z ciałem i ekspresja, której obie te wartości są nośnikiem wpływają na kształtowanie estetyki i mody czasów, w których funkcjonujemy.

Kulturowe i podmiotowe kreowanie wizerunku kobiety posiada zauważalny związek z prezentowaniem, podkreślaniem lub kamuflowaniem kobiecego ciała, oraz $\mathrm{z}$ akcentowaniem wybranych elementów jego sylwetki - to zjawisko obecne 
w doświadczeniu wszystkich znanych nam społeczeństw i społeczności. Posiada ono dość interesujący choć często trudny do precyzyjnego zinterpretowania, a gromadzony poprzez wieki materiał faktograficzny w wielu dyscyplinach podstawowych zwłaszcza historycznej, antropologicznej (a wcześniej etnograficznej) czy obecnie socjologicznej (zarówno w jej nurcie feministycznym, jak i w tak zwanej socjologii dnia codziennego czy socjologii ciała) ${ }^{1}$ (Vigarello, 2011; Corbin, 2013; Ziółkowska et al., 2009).

Mimo tak już znacznego nagromadzenia refleksji teoretycznej o tym przedmiocie i jego praktycznych (prakseologicznych, projektowych) aspektach, warto zarówno z poznawczego, jak i praktycznego punktu widzenia ponawiać próby jego teoretycznego oglądu, mając na uwadze niespotykaną w historii, a współcześnie doświadczaną dynamikę owej praktyki i jej teoretyczno-prakseologiczne (projektowe) wyzwania.

Z uwagi na powyższe moje rozważania zacznę od podkreślenia, iż kreowanie wizerunku kobiety, istoty doświadczającej psychoemocjonalnej motywacji do dekoratywności swojej osoby oraz podkreślania pewnych atutów własnej sylwetki, jest procesem złożonym $\mathrm{z}$ wieloetapowych działań twórczych odpowiadających na ujawnione potrzeby odbiorcy. Analizując historię ubioru i jej bogatą ikonografię można zauważyć, że kobiety w przeszłości dość często a obecnie z coraz większą intensywnością poddają się nowym inspiracjom i uzależnieniom od aktualnie kreowanych i popularyzowanych w kulturze modnych często bardzo odważnych wzorów atrakcyjności estetycznej.

Kontekst poczucia piękna mającego znaczenie w procesie kreowania własnego wizerunku często jest dość umowne, nie można jednoznacznie określić tej wartości w ujęciu ogólnym, lecz tylko indywidualnym, często bardzo subiektywnym. Moda przez swą zmienność i płynność preferencji estetycznych wyklucza jednoznaczne skatalogowanie formy znaczeniowej tego pojęcia, co powoduje niekończącą się próbę rywalizacji piękna i brzydoty ${ }^{2}$ (Eco, 2005; 2007).

Do XX w. wygląd kobiety precyzyjnie określał przynależność etnicznokulturową, pozycję społeczną oraz jej status. Ubiór stanowił bardzo istotny element

\footnotetext{
${ }^{1}$ Patrz m.in.: Georges Vigarello (red.), 2011, Historia ciała. Od Renesansu do Oświecenia. T. 1. Wyd. Słowo/obraz terytoria Gdańsk; A. Corbin (red.), 2013, Historia ciała. Od Rewolucji do I wojny światowej. T. II, Wyd. Słowo/obraz terytoria Gdańsk; J.-J. Courtine (red.), 2014, Historia ciała. Różne spojrzenia. Wiek XX. Tom III, Wyd. Słowo/obraz terytoria Gdańsk; A. Chałupnik i in. (red.), 2008, Antropologia ciała. Zagadnie i wybór tekstów. Wyd. Słowo/obraz terytoria Warszawa; M. Brocki, 2001, Język ciała w ujęciu antropologicznym. Wyd. Astrum; H. Jakubowska, 2009, Socjologia ciała. Wyd. Naukowe UAM Poznań; B. Ziółkowska i in. (red.), 2009, Ciało w kulturze i nauce. Wyd. Naukowe Scholar, Warszawa.

${ }^{2}$ Świetnie tę zależność uzasadniają treści i ilustracje zawarte w dwóch monografiach pod red. U. Eco, 2005, Historia piękna. Dom Wyd. Rebis Poznań i U. Eco, 2007, Historia brzydoty. Dom Wyd. Rebis Poznań.
} 
w komunikacji z otoczeniem. Kobieta nie traktowała ubioru jako płaszczyzny do wyrażania własnej indywidualności, a przyjęte w danej grupie zasady kształtowania wizerunku były ściśle przestrzegane. Trendy wyglądu kobiety wytyczano w ośrodkach politycznych władzy i tworzonej w obrębie jej mecenatu, głównie w środowiskach monarszych, tj. dworów cesarskich, królewskich czy książęcych (np. dwory francuskie, hiszpańskie, angielskie, niderlandzkie, niemieckie, włoskie). Historia ubioru w swoim bogactwie artystycznym dowodzi o silnych fluktuacjach jakim ulega strój człowieka na przestrzeni zmian kulturowych. Kreacje artystyczne w ubiorze, powstające na drodze autorskich działań twórczych i poszukiwań nowych form wyrazu są wynikiem inspiracji historycznych, kulturowych i społecznych.

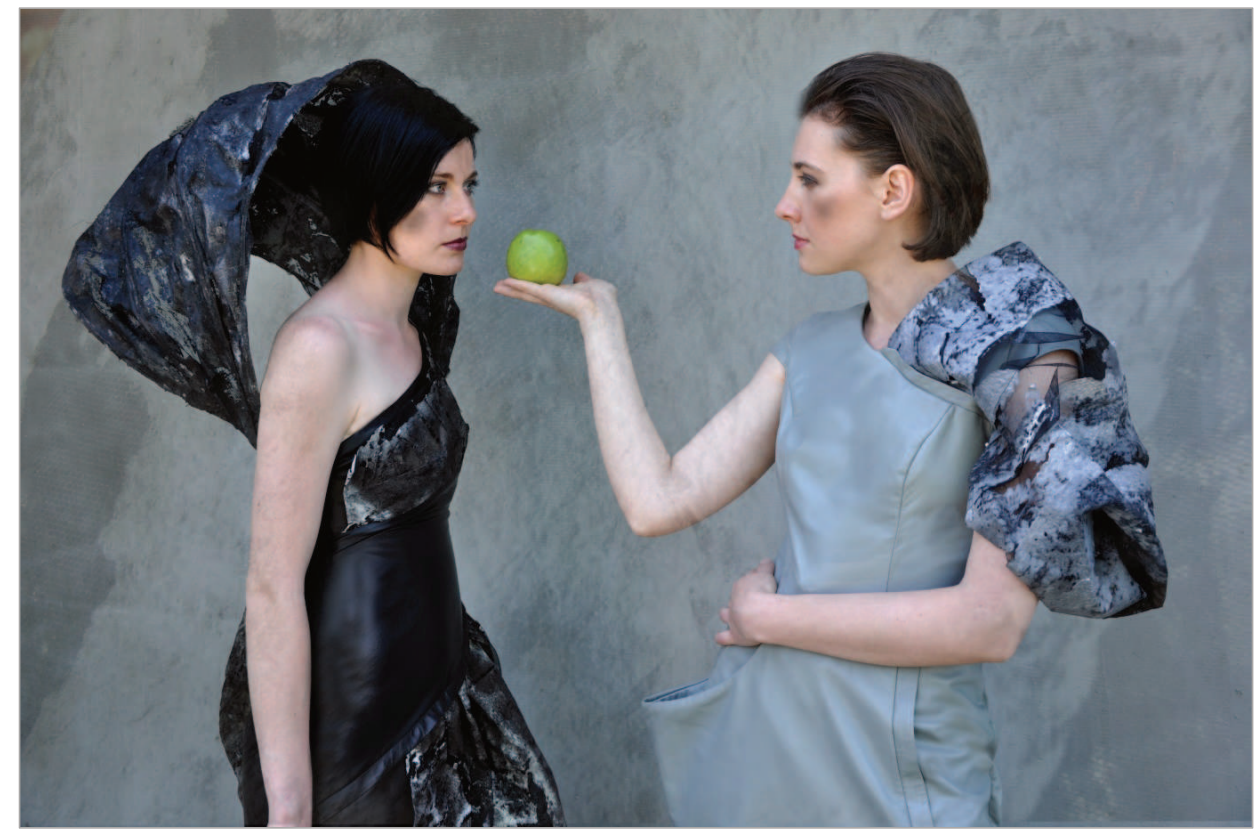

Fot. 1. Modele z kolekcji „Fibryle w skórzanej oprawie”, autorka modeli i stylizacja sesji: M.I. Kostrzewa, $2009 \mathrm{r}$.

Bezsprzecznym jest fakt, że ubiór jest cennym nośnikiem informacji o człowieku i mimo wielorakim wpływom kulturowym pozostaje ważnym i czytelnym komunikatem.

Obraz kobiety, będący świadomie lub nieświadomie wykreowanym wizerunkiem, który postrzegany jest podczas pierwszego kontaktu, stanowi istotny zespół cech percypowanych przez spostrzegającego. Wpływają one wprost proporcjonalnie na wzbudzanie chęci poznania innych, bardziej ukrytych cech kobiecej osobowości. Można wyrazić, że w powstawaniu wizualnego obrazu kobiety decydujące znacze- 
nie ma jej wygląd zewnętrzny - wywiera istotny wpływ na dokonywaną przez obserwatora waloryzację oceny jej wizerunku.

Mimo intensywnie zachodzących zmian społecznych i estetycznych współczesna kobieta posiada wyraźną potrzebę posiadania i wykorzystywania narzędzi oraz wiedzy do kreowania własnego wizerunku jako środka do wyrażania własnej ekspresji i osiągania zamierzonych celów. A jednym z nich jest, to aby wyglądać atrakcyjnie dla środowiska, w którym preferowane są pewne wzorce estetyczne, np. trendy modowe obowiązujące tu i teraz. Jest więc bezsprzeczne, że osoby w fazie nawiązywania ze sobą relacji, wizerunek, na który składa się również ubiór, traktują ów wizerunek jako istotne personalne antrua, skupiające uwagę i wyznaczające taktykę zachowań wobec siebie. Tak więc chęć zaakcentowania podstawowych rysów podmiotowej tożsamości, wydobycia indywidualnego charakteru osoby mając na uwadze cechy osobowościowe i osobistą ekspresję, wymusza na projektancie ubioru wnikliwą analizę personalną, pracy nad wizualną dramaturgią obrazu postaci, ujawniającą przy tym nowe, najbardziej pożądane walory estetyczne.

Projektant ubioru tworząc kolekcję ubiorów, która pretenduje do znalezienia się w systemie powtarzalności ściśle związanym z modą, stara się odpowiadać na ujawnione potrzeby odbiorców. Poszukuje dostępu do wiedzy o preferencjach posiłkując się trendami w modzie danej społeczności, grupie lub indywidualnej osobie ${ }^{3}$ (Kostrzewa, 2016a: 204-205).

Kreacja w modzie jest zatem reprezentowana przez zjawiska bardzo zindywidualizowane, związane ściśle z procesem twórczym artysty-projektanta, zindywidualizowanej jednostki, czasem i krajem, w którym powstaje, oraz z artystyczną wyobraźnią i osobistym poczuciem estetyki ${ }^{4}$ (Kostrzewa, 2014: 119).

Moda jak pisze Georg Simmel jest szczególną formą życia, która ma zapewnić kompromis między tendencją do społecznego zrównania a tendencją do indywidualnej odrębności. Składają się na to poszczególne aspekty psychologiczne mody ${ }^{5}$. (Simmel, 2006: 22) Analizując modę, można zauważyć, że jej artystyczny wymiar koresponduje zarówno z szeroko rozumianą przyszłością, jak i dziedzictwem, wywodzącym się z naszej kulturowej przeszłości. Jest obrazem potrzeb ludzi i otaczającego ich świata. Wyraża rodzaj zmian, jakim ulega człowiek zarówno przez zjawiska związane z procesem socjologicznym, jak i przez komunikację marketingową. Pod względem socjologicznym moda, jest wytworem podziału klasowego. Sygnali-

\footnotetext{
${ }^{3}$ Zagadnienie to rozwijam w artykule: Rola ubioru jako elementu twórczej ekspresji i narzędzia komunikacji niewerbalnej we wspótczesnym świecie, [w:] P. Łuszczykiewicz, B. Kowalczyk i M. Zdrowicka-Wawrzyniak (red.), 2016, Medialny obraz rzeczywistości, UAM WPA Kalisz, s. 204-205.

${ }^{4}$ Zagadnienie to rozwijam w artykule: Kreowanie wizerunku kobiety w kontekście zmieniającej się mody, preferencji estetycznych i poszukiwań twórczych projektantów w przestrzeni wybranych kultur, [w:] J. Wojnowska-Radzińska (red.), 2014, Kobieta i płeć w dyskursie aksjonormatywnym, UAM WPA Kalisz, s. 119.

${ }^{5}$ G. Simmel, Drzwi i mosty. Wybór esejów, Oficyna Naukowa, Warszawa 2006, s. 22.
} 
zuje z jednej strony akces do równych sobie z drugiej zaś wyodrębnienie owych równych jako grupy w stosunku do niżej postawionych. Pod wpływem mody zmieniają się nie tylko społeczne formy ubioru, ale również, wszystko co człowieka otacza, od poglądów estetycznych, stylów, zachowań do ideologii. Jednak jak mawia G. Simmel moda tj. nowa moda przystoi tylko stanom wyższym, podkreślając równość jednego stanu i jednocześnie różnicę w stosunku do niżej postawionych ${ }^{6}$ (Simmel, 2006: 22).

Mając na względzie dokonania na płaszczyźnie współczesnej kultury i sztuki wizualnej oraz własne doświadczenia artystyczne dotyczące kreacji w ubiorze, dochodzę do osobistych przemyśleń, wniosków, osiągnięć i zamierzonych celów ilustrowanych za pomocą autorskiej twórczości.

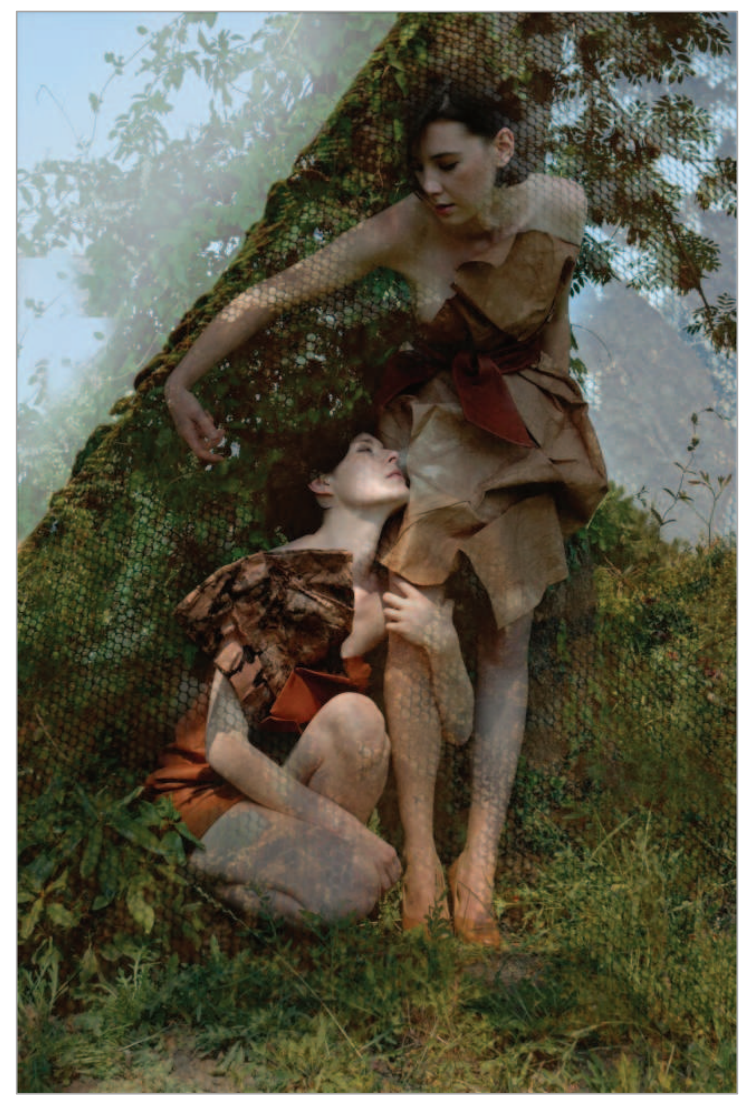

Fot. 2. Modele autorskie z kolekcji „Fibryle w skórzanej oprawie”, stylizacja sesji i grafika: M.I. Kostrzewa, 2009 r.

\footnotetext{
${ }^{6}$ Tamże, s. 23.
} 
Ponieważ kreowanie wizerunku poprzez ubiór jest formą twórczości - w sposób fizyczny najbliższą człowiekowi - ze względu na tę jej właściwość racjonalizowania i porządkowania wiedzy dotyczącej tego zagadnienia i formy praktyki, przez dłuższy czas było marginalizowane i niedoceniane ${ }^{7}$ (Kostrzewa, 2016b: 146-147).

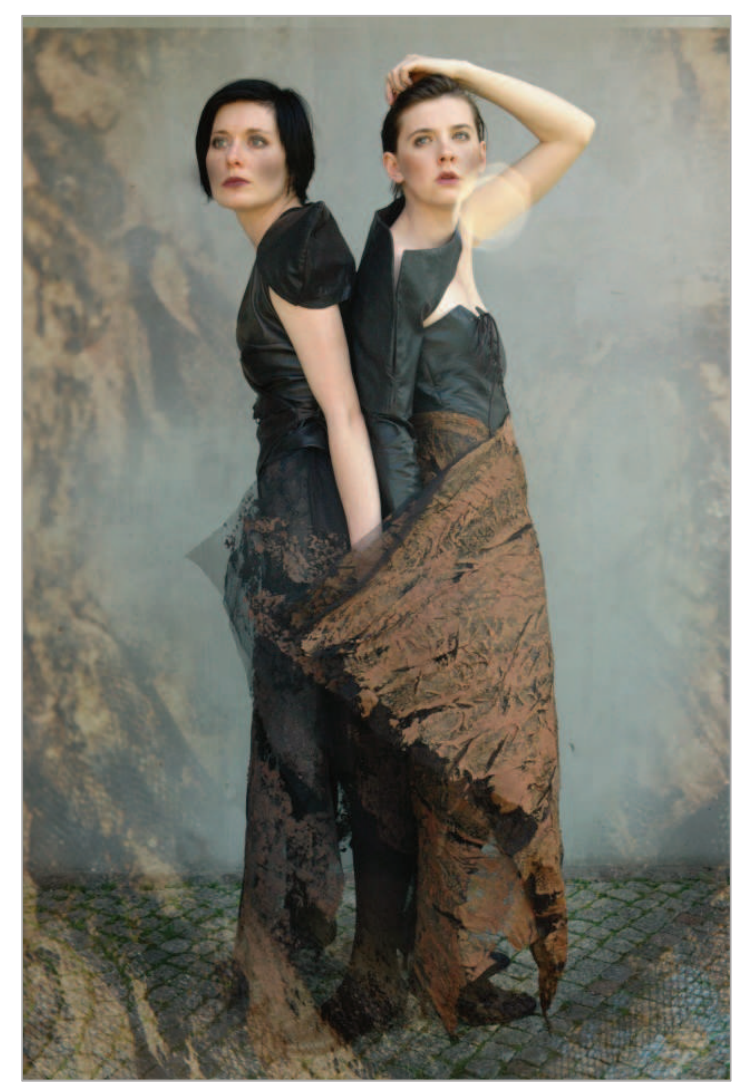

Fot. 3. Modele z kolekcji autorskiej „Fibryle w skórzanej oprawie”, grafika i stylizacja sesji fotograficznej: M.I. Kostrzewa, 2009 r.

Niezależnie od naszego stosunku do fizycznej wartości ubioru oraz tego jak silnie chcemy pokazać własną niezależność od trendów mody, ubiór jest istotnym elementem wizualnego odbioru człowieka podobnie jak opakowanie stanowiące nieuchronny wstęp do naszego doświadczenia przedmiotu. Rola ubioru, istotnego

\footnotetext{
${ }^{7}$ M. Kostrzewa, Kreowanie wizerunku kobiety z uwzględnieniem relacji mody i ciała, [w:] Piękno $i$ brzydota $w$ ujęciu artystycznym $i$ humanistycznym, w pracy zbiorowej pod red. S. Romecka, A. Gałkowski, A. Grudzińska-Pham, wyd. ASP im. Wł. Strzemińskiego w Łodzi, 2016, s. 146-147.
} 
elementu kultury, który w przejściu od nowoczesności do ponowoczesności, od modernizmu do postmodernizmu i od społeczeństwa przemysłowego do kreatywnego oraz wzrostu znaczenia indywidualizmu i konsumpcjonizmu w życiu człowieka i grup społecznych, ma duży wpływ na kształtowanie wizerunku osobowego.

Odwołując się do tezy mówiącej o tym, że język jako metoda komunikacji społecznej służy do porozumiewania się międzyludzkiego, jako wytwór życia społecznego jest jednocześnie bytem warunkującym istnienie i możliwość funkcjonowania grup i społeczeństw. Potwierdzenie tej tezy znajdujemy wokół siebie na co dzień chociażby w wyglądzie poszczególnych środowisk młodzieżowych. Szczególnie wyraziste są fascynacje młodzieży wschodniej i środkowej części Europy muzyką, obyczajami, ubiorem, ekspresją słowa itp. rówieśników z krajów zachodnich, z którymi starają się utożsamiać tworząc nowy styl w ubiorze będący kolejnym wzorcem - odmiennym wobec wschodnioeuropejskich cywilizacyjnych reguł systemowych ${ }^{8}$ (Pełka, 2013: 1).

Projektując kolekcje ubiorów powielanych przemysłowo zarówno męskie, na przykład w liniach takich jak: Ted Lapidus, Lantier, Vesari, Polo, Personality, Hacker oraz damskich takich jak np.: Polo Lady, Veronique, Teomina, Mawex, MStylish, Gorsenia, Kris Line oraz innych, w tym ubiorów unikatowych, o bardziej osobistym charakterze ekspresji plastycznej, zdobyłam jak sądzę nie tylko dostateczne doświadczenie praktyczne lecz również refleksję teoretyczną. Moja działalność artystyczna rozwija się wokół trzech zasadniczych kierunków działań, które pomagają i wzmacniają metody pracy artystycznej i naukowej. Pierwszy, to twórczość związana ze sztuką czystą i pracą projektową ukierunkowana na przemysł mody. Drugi obszar moich działań to twórczość pozwalająca na większą swobodę artystyczną. Jest to trudno uchwytny aspekt i wymiar świata autorskich idei, wymykający się często precyzyjnym naukowym określeniom. Zmierza on do tworzenia ubiorów - obiektów; do odkrywania nowych wartości i możliwości projektowych; do tworzenia wizualnego wizerunku kobiety ponadczasowej, wolnej, świadomej własnej wartości, nieuzależnionej od ulotnych trendów mody sezonowej.

Ten dwubiegunowy rodzaj twórczości pozwala na zdobycie doświadczenia praktycznego jak i teoretycznego zarówno w obszarze sztuki jak i silnie rozwijającego się designu przemysłowego. Zarówno w jednym jak i drugim obszarze pracy finalnym efektem były kolekcje adresowane do konkretnego odbiorcy zawsze o zdefiniowanych potrzebach, dla którego ubiór miał podkreślać pewne jego cechy, współtworząc tożsamość.

W każdym przypadku pracy projektowej istotne jest indywidualnie spojrzenie twórcy na ubiór i na osobę, do której jest on kierowany mimo, iż forma ubiorów związana jest od wieków ze zjawiskiem mody i ulega trendom społecznym i obwarowaniom technologicznym. Od czasu industrializacji ubiór rozpatrywany jest rów-

${ }^{8}$ A. Pełka, Z (politycznym) fasonem. Moda młodzieżowa w PRL i NRD, Słowo, obraz, terytoria, Gdańsk 2013, s. 1. 
nież jako ważne ogniwo designu przemysłowego, który narzuca pewne rygory i kryteria projektantom. W projektowaniu przemysłowym twórca powinien umiejętnie posługując się własną wrażliwością inicjować powstanie, zgodnych z potrzebami i estetyką szerokiego grona odbiorców, formy produktów o konkretniej funkcji. Projektant powinien komunikować się z odbiorcą wzbudzając jego chęć pożądania proponowanej kolekcji, zgodnej w swej formie i treści z jej założeniami.

Powinien prezentować jak największy zakres wiedzy projektowej, psychologicznej, antropologicznej, socjologicznej i marketingowej aby trafnie artykułować swoje wizje adresowane do konkretnych kategorii osób, grup i środowisk społecznych.

Powinien charakteryzować się kreatywnością, przedsiębiorczością, umiejętnością współpracy z zespołem i trafnością podejmowanych decyzji. Cechy te podobnie jak sprawne posługiwanie się językiem werbalnym pozwalają odczytywać intencje odbiorcy i formułować trafne komunikaty wizualne. Mówiąc o ekspresywnej funkcji stroju - w znaczeniu seksualnym - kluczowym elementem jest forma, która ma za zadanie podkreślać ekspresję seksualna sylwetki a taką niewątpliwie powinna posiadać bielizna.

Ubiór przekształcając się z wytworu rzemiosła w produkt potężnej branży przemysłowej stał się elementem swoistej ścieżki produktów gotowych do noszenia, czyli kolekcji ubrań dostępnych w sklepach, z produkcji seryjnej, funkcjonujących

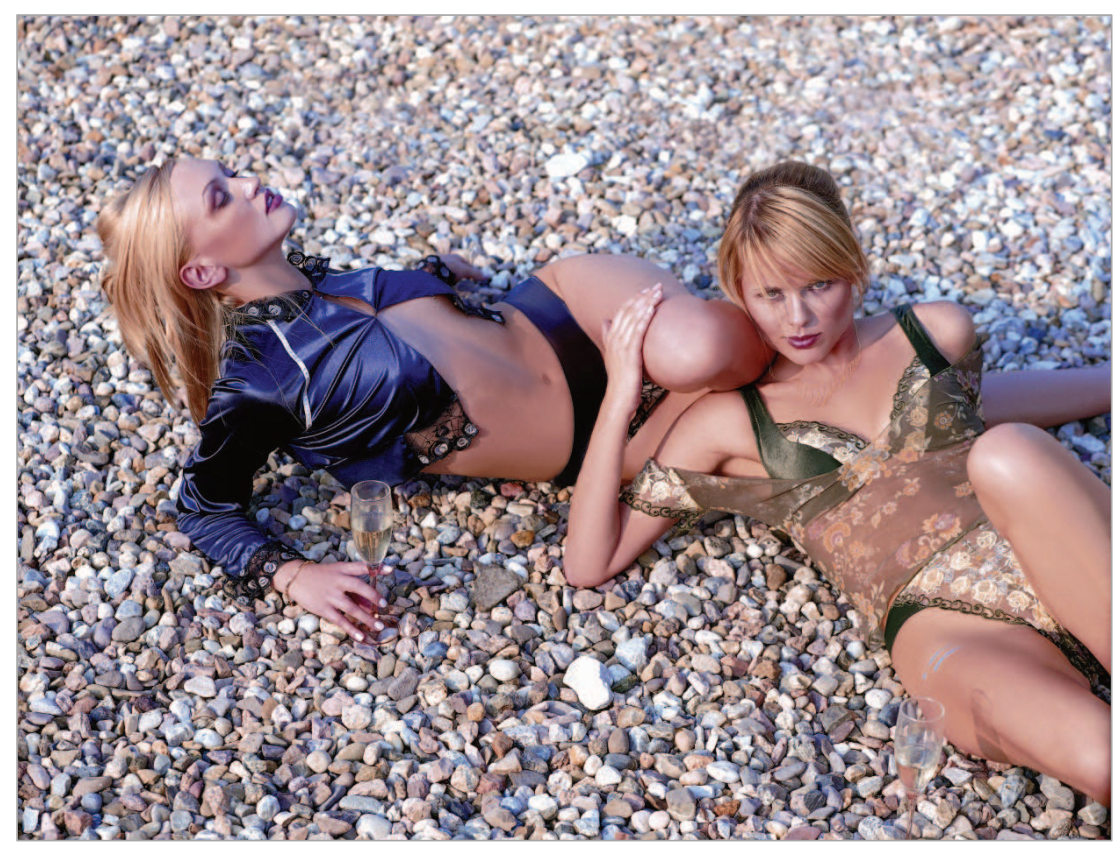

Fot. 4. Model z kolekcji „Sweet Dreams”, projektantki: M. Kostrzewa, A. Wereszka, 2004 r., fotografia: Studio Wrzesień. Moda.com.pl 
pod nazwą kolekcji Prêt-à-porter. W odróżnieniu od kolekcji haute couture - tak zwany modny ubiór - jest siłą napędową, która generuje największe profity dla współczesnych korporacji. Współczesny projektant ubiorów permanentnie poszukuje nowych sposobów przyciągania uwagi aby mógł wywoływać silne wrażenie i zmieniać wizerunek współczesnego człowieka.

W projektowaniu modnego stroju wykorzystuje się kreatywność i pomysłowość artystyczną w każdej dziedzinie: w formie i strukturze kreacji, w konstrukcji technik produkcji masowej, w metodach (technologii) wytwarzania drukowania i barwienia tkanin. Kreatywność projektantów, dzięki której ubrania zyskują aurę atrakcyjności, jest bardzo cenną cechą, która wzbogacona o pozostałe, a konieczne w pracy designerów umiejętności, decyduje o ich pozycji, prestiżu i sukcesie rynkowym wykreowanego produktu. W kulturze współczesnej zauważamy wielki i niezaspokojony głód pomysłów i obrazów będących tworzywem mody, co ilustrują szybko zmieniające się klatki wideoklipów i przygotowane z niezwykłym rozmachem, coraz bardziej wizjonerskie spektakle mody. Obserwowane zmiany dowodzą, że moda pożąda transfuzji energii jaka tętni w sztuce współczesnej, karmi się nią, czerpiąc z różnych jej obszarów, między innymi: filmu, teatru, literatury czy muzyki. Trzeba sobie jednak zadać pytanie, czemu ona służy i jaką rolę w komunikacji artefaktycznej odgrywa przedmiot mody wykreowany przez projektanta? Jakie zadnie mają spełniać współczesne ubiory? Jak mają wpływać na nasze życie i jak mają kształtować naszą codzienność bądź niecodzienność?

Jest pewne, że moda jest silnym zjawiskiem socjologicznym i działa w imię estetyki współczesności, kultywuje piękno krótkotrwałe i przemijające, gdzie wymóg nowości jest często jedynym kryterium sądu estetycznego. To podążanie za innowacyjną formą i strukturą produktu mody zmierza w kierunku prowokacji, gdzie jak sugeruje Roland Barthes, umiejscowieni jesteśmy w czasach, w których osąd otaczającego nas świata nie jest podyktowany przeciwstawieniem dobra złu, lecz tego co nowe staremu9 (Barthes, 1997: 220). Prawdą mody jest nieświadoma świadomość jądra czasu w sztuce ${ }^{10}$ (Adorno, 1994: 350). Autor zwraca uwagę na normatywny charakter mody, który ściśle związany jest z duchem czasu. Jako, że dzieło i jego rozwój jest uwarunkowany dalszym jego istnieniem w czasie, trzeba mieć świadomość, że czas ten równie dobrze może spowodować, iż dzieła zamilkną, bądź staną się niemożliwe do zinterpretowania. Podobno „,oraz mniej dobrego pochodzi z przeszłości” - konstatuje filozof T. Adorno. Skoro zdarzają się dzisiaj tezy poddające pod wątpliwość przeszłość nie stanowi już ona zasadniczego punktu odniesienia w projektowaniu dzieła modnego, możliwym jest według mnie dzieło w postaci kolekcji ubioru, które gardzi czasem, które sięga do przeszłości dostosowując ją do własnych potrzeb.

\footnotetext{
${ }^{9}$ R. Barthes, Przyjemność tekstu, tłumaczenie Adriana Lewańska, Aletheia Warszawa 1997, s. 220.

${ }^{10}$ T. Adorno, Teoria estetyczna. PWN Warszawa 1994, s. 350.
} 
Taki rodzaj pracy projektowej, w której idea artystyczna przeradza się w formę użytkową zawierającą własną narrację, analogiczną często do funkcji literatury, stwarza wiele możliwości samorealizacji twórczej. Jako twórca realizujący swoje prace zarówno w obszarze sztuk pięknych jak i sztuk projektowych mogę pozwolić sobie na stwierdzenie, że sztuka to sposób patrzenia na świat a moda jako narzędzie komunikacji może być najbardziej intymnym, najbardziej osobistym i najskuteczniejszym sposobem pobudzania interakcji międzyludzkiej. Działania artystyczne są bardzo skuteczne w przekształcaniu pospolitej materii i struktury tkackiej płótna w dzieło malarskie, obiekt o odkrywczej formie, rzeźbę miękką czy instalację. Pozwalają wizualizować ekspresję twórcy jego kreatywność i obecnego w procesie działań artystycznych ducha inspiracji.

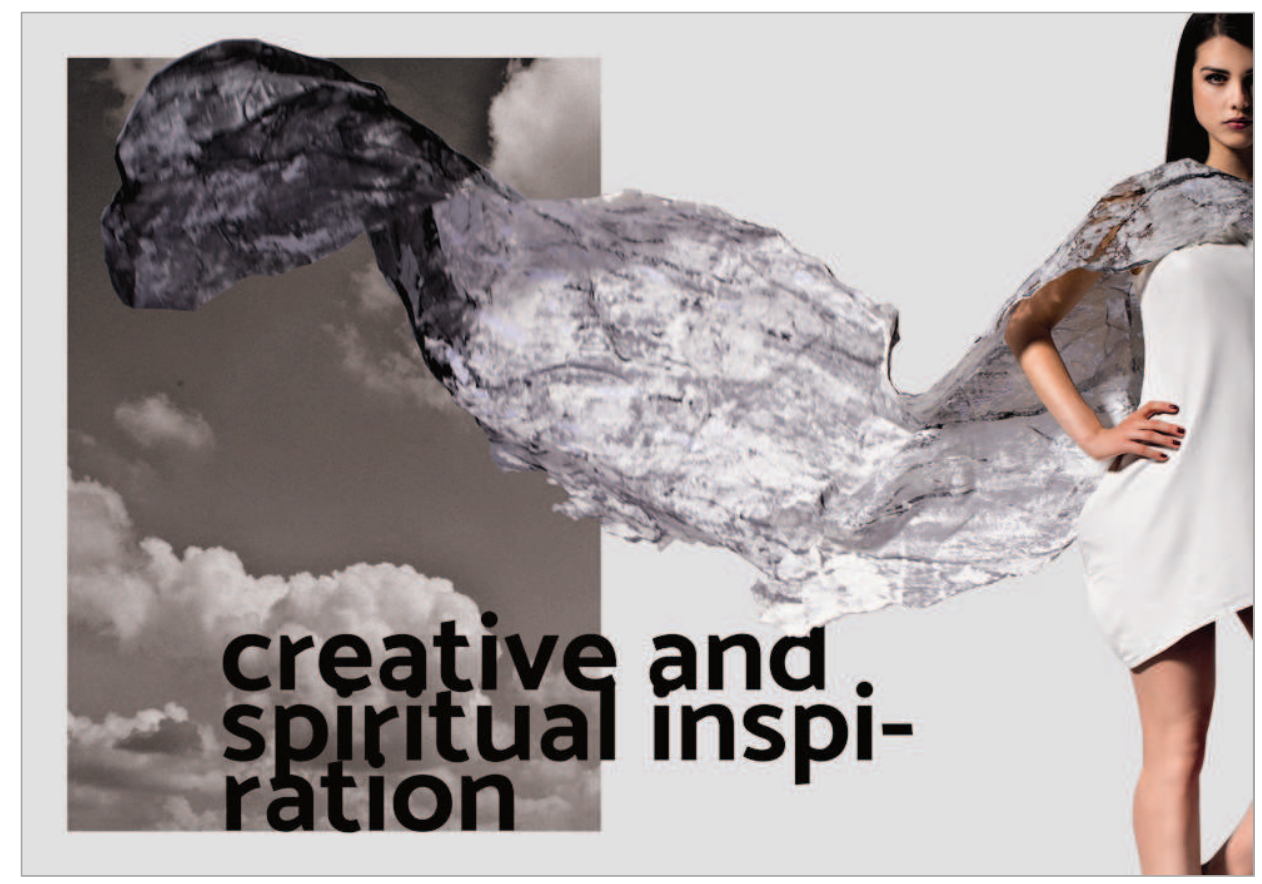

Fot. 5. Model z kolekcji „Sea Grey”, autorka: M.I. Kostrzewa, fotografia: Grid studio, 2016 r.

Jestem zdania, że współczesny ubiór jest często postrzegany jako interaktywne medium, o silnym potencjale energii i dużej możliwości oddziaływania, nie unikające krytyki ani dialogu z odbiorcą o odmiennej estetyce. Taka forma ubioru jako narzędzia wizualnej komunikacji społecznej, służy konstruowaniu naszych pragnień, które zinterpretowane przez kreatorów mody, staną się inicjacją nowych, coraz bardziej ekscentrycznych projektów. 


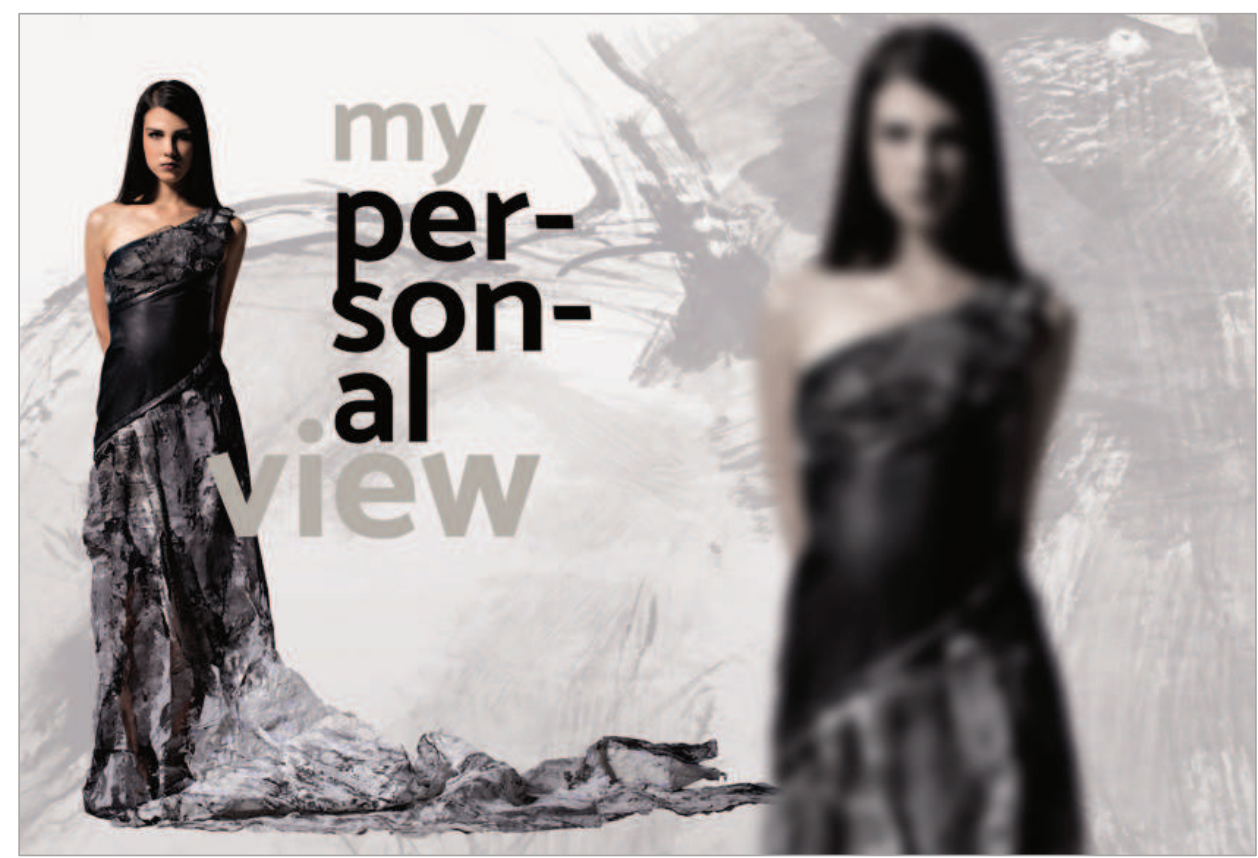

Fot. 6. Model z kolekcji „Sea Grey”, autorka: M.I. Kostrzewa, fotografia: Grid studio, 2016 r.

\section{Kreacja w ubiorze jako jedna $\mathrm{z}$ form wyrażania ekspresji przez studentów Pracowni Sztuk Projektowych WPA w Kaliszu}

Aby pełniej przedstawić interesujące mnie zagadnienie postanowiłam w swoich badaniach uwzględnić rezultaty twórczych działań realizowane przez studentów pracowni artystycznej, którą prowadzę. Powoływane przez młodych adeptów sztuki kreacje w ubiorze, posiadają nośnik ekspresji plastycznej ujawniany i kształtowany w procesie edukacji plastycznej na Wydziale Pedagogiczno-Artystycznym w Kaliszu.

Relacje mody i sztuki wzajemnie się przenikają, a znaczenie terminu 'moda' nie ogranicza się tylko do stroju, ale również do systemów i mechanizmów regulujących ludzkie zachowania, kształtujących ciągle zmieniającą się i wzbogacającą o nowe elementy obyczajowość ${ }^{11}$ (Kostrzewa, 2016c: 124). Słowo Art i Fashion w XXI wieku ma tożsamą moc eksploracyjną a moda podobnie jak kultura może dziś dotyczyć bardzo szerokiego spektrum działań.

${ }^{11}$ Patrz: M. Kostrzewa, Eksperymenty twórcze wokót sztuki, mody, edukacji i ich rola w budowaniu tożsamości artystycznej środowiska akademickiego w Kaliszu [w:] S. Kowalska, Dziedzictwo kulturowe miasta Kalisza i regionu Południowej Wielkopolski, Poznań/Kalisz WPA UAM 2016; Chwalba (red.), Obyczaje w Polsce. Od średniowiecza do czasów wspótczesnych. Warszawa 2006; B. Łaciak (red.), Obyczajowość polska początku XXI wieku- w procesie przemian. Warszawa 2014; M. Szpakowska (red.), Obyczaje polskie. Wiek XX w krótkich hastach. Warszawa 2008. 


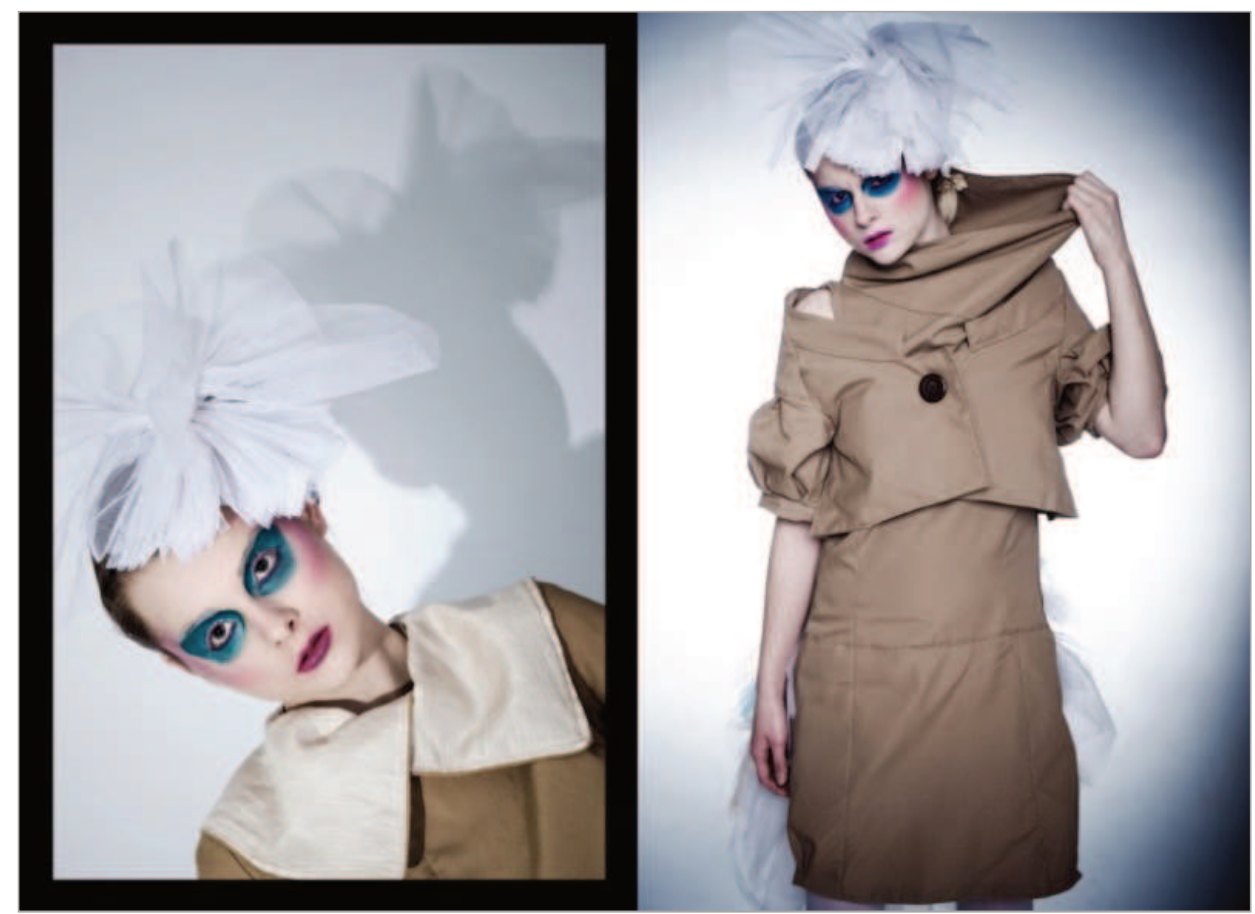

Fot. 7. Fragment licencjackiej kolekcji ubiorów „Siła Kobiety”, autor: K. Piętka, promotor: prof. zw. A. Nawrot, $2008 \mathrm{r}$.

Bardzo często efekty prac projektowych i wzorniczych stają się realną formą ubiorów adresowanych do konkretnego odbiorcy, które w odpowiedniej stylizacji i formie, która sama w sobie jest komunikatem interpretującym znaczenie siły kobiety w ujęciu artystycznym.

W działaniach $\mathrm{z}$ zakresu projektowania i kreowania najbliższego otoczenia człowieka sprawdzają swoje umiejętności studenci i studentki zarówno z Polski, jak i z innych ośrodków europejskich od kilku lat współpracujących z Uniwersytetem im. A. Mickiewicza w ramach programu Erasmus. Daje to możliwość wymiany myśli artystycznej na płaszczyźnie międzykulturowej i konfrontacji plastycznej.

Podążając tropem ekspresji artystycznej wyrażanej przez ubiór i z jego udziałem warto zauważyć rolę jaką odgrywa forma pokazu jako spójnego ideowo działania przedstawiającego szerokiemu gronu odbiorców wizję mody jako propozycji artystycznego kreowania wizerunku. W pokazach biorą udział ubiory wykreowane przez studentów pochodzących często z różnych środowisk, które wzbogacane są swoją ekspresją nie tylko doraźnie odczuwanych i przeżywanych doznań estetycznych lecz wpisują się na trwałe w dorobek kulturowy środowiska akademickiego i lokalnego. Pokazy realizowane są z udziałem studentów i społeczności lokalnej w formie 
cyklicznie odbywających się imprez w przestrzeniach miejskich. Odgrywają ważną rolę próby odnalezienia się $\mathrm{z}$ autorskimi wizjami mody $\mathrm{w}$ uniwersalnej przestrzeni życia. Zadanie to będące próbą ingerowania w przestrzeń, w której funkcjonujemy wymaga pewnych zaplanowanych działań. Na temat pokazu posiadającego szczególny walor komunikacyjny i ubioru jako składnika komunikacji międzyludzkiej pisze profesor S. Puppel w publikacji „Sea Grey”:

„Jako gatunek biologiczny występujemy na tle wielkiej różnorodności biosfery. Wespół z innymi jej przedstawicielami 'prezentujemy się’ w określony - biologicznie zdeterminowany - sposób w 'uniwersalnej przestrzeni życia' (ang. Universal Space of Life). Nasza czysto biologiczna prezentacja ma charakter 'pokazu' (ang. display), który łączy nas z wszystkimi uczestnikami tejże przestrzeni, a więc poprzez biologicznie zdeterminowaną wizerunkową odmienność.

Jednocześnie jako gatunek posiadający i wytwarzający kulturę nadaliśmy pokazowi szczególny walor komunikacyjny. Tworząc 'uniwersalną przestrzeń komunikacyjną' (ang. Universal Communication Space), stosujemy ubiór jako szczególny wymiar nie tylko naszych zasobów komunikacyjnych, lecz także jako niezbywalny element naszej jednostkowej jak i zbiorowej/wspólnotowej (narodowej, etnicznej, zawodowej, etc.) tożsamości” (Puppel zob. Kostrzewa, 2016d: 13).

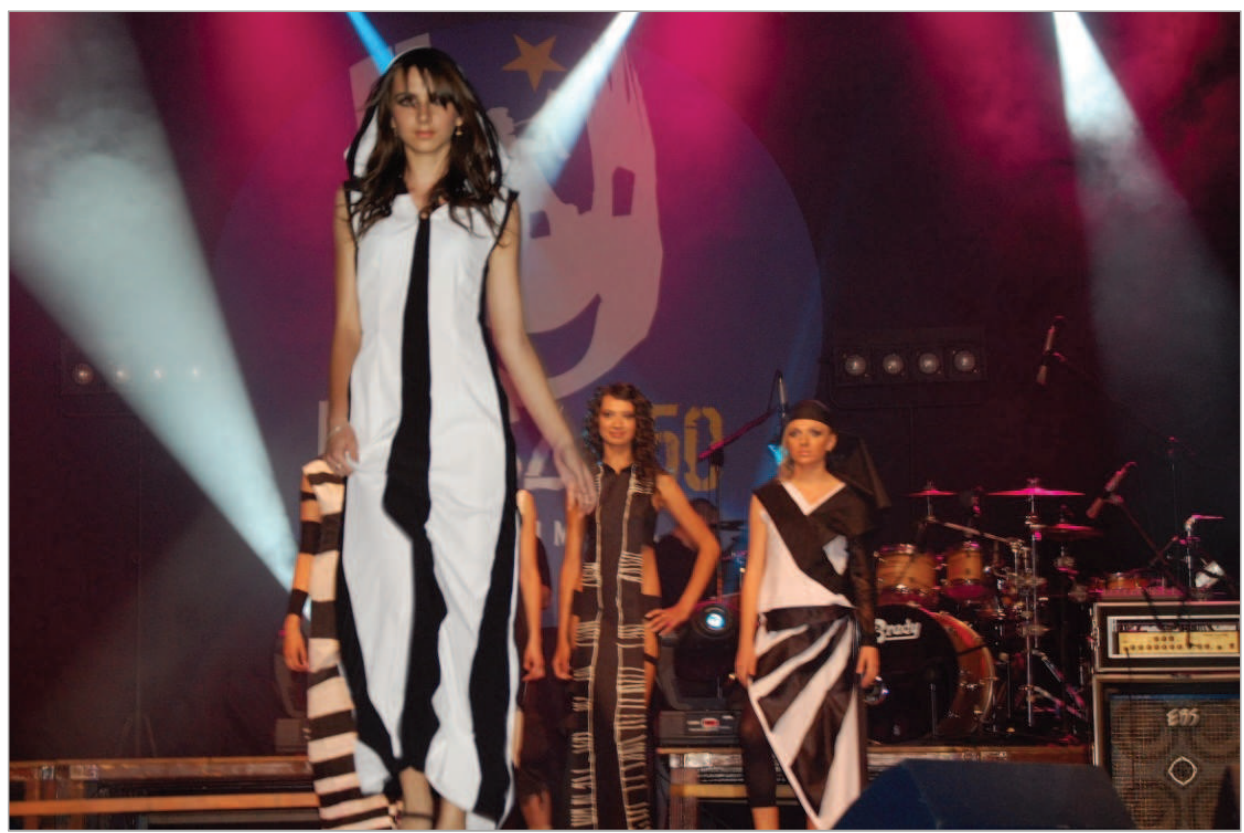

Fot. 8. Realizacje studentów prezentowane podczas pokazu pt. „Siła Wyobraźni”, scena pod Teatrem im. W. Bogusławskiego w Kaliszu, reżyseria pokazu: M.I. Kostrzewa, 2007 r. 
Rola i znaczenie tych charakterystycznych przez swą unikatowość i sposób artykułowania ekspresji plastycznej przekazywanej w formie kinetycznych obrazów prezentowanych podczas pokazów, jest znacząca nie tylko dla procesu dydaktyczno-organizacyjnego dla również dla budowania środowiska kompetentnego do odbioru sztuki.

„W ten sposób pokaz ubioru stał się częścią naszej ekspresywności/performatywności (ang. expressivity/performativity) obejmującej język i inne wytwory w społeczno-kulturowym wymiarze naszego gatunkowego trwania.

W ten sposób ubiór wespół z językiem i szeroko rozbudowanym wymiarem technologicznym bierze udział w procesie gatunkowo unikatowej 'transkomunikacji' (ang. transcommunication), tj. wewnątrzgatunkowej komunikacji poprzez całe bogactwo kultur lokalnych i wszelkich wspólnot komunikacyjnych" (Puppel zob. Kostrzewa, 2016d: 13).

Konkludując rozważania związane z ubiorem jako elementem twórczych działań zmierzających do wyrażania ekspresji osobowości i podkreślenia wybranych aspektów wizualnego obrazu kobiety, pozwolę sobie na stwierdzenie, że ten złożony proces, w którym ważną rolę odgrywają kwestie kulturowe i estetyczne posiada istotną rolę we współczesnej komunikacji artefaktycznej. Starałam się w swoich rozważaniach potwierdzić tezę mówiącą o tym, że język jako metoda komunikacji społecznej służący do porozumiewania się międzyludzkiego, jest jednocześnie narzędziem określającym możliwość funkcjonowania grup i społeczeństw. Można to zauważyć w różnych przestrzeniach społecznych, w których dane nam jest funkcjonować. Wygląd poszczególnych środowisk młodzieżowych, w których ubiór, będący w bezpośrednim kontakcie z ciałem i ekspresja, której obie te wartości są nośnikiem podkreśla wizerunek kobiety, a ten świadomie bądź nieświadomie kreowany niesie ze sobą silny nośnik znaczeniowy/komunikacyjny i bezustannie wpływa na kształtowanie zmiennej estetyki i mody czasów, w których funkcjonujemy.

\section{Bibliografia}

Adorno, Th. 1994. Teoria estetyczna. Warszawa: PWN.

Agamben, G. 2010. Nagość. Warszawa: WAB.

Barthes, R. 1997. Przyjemność tekstu. Warszawa: Aletheia.

Bauman, Z. 2013. Razem osobno. Kraków: Wydawnictwo Literackie.

Brocki, M. 2001. Język ciała w ujęciu antropologicznym. Wrocław: Astrum.

Chałupnik, A., Jaworska, J., Kowalska-Leder, J., Kurz, I. i M. Szpakowska (red.). 2008. Antropologia ciała. Zagadnienia i wybór tekstów. Warszawa: WUW.

Chwalba, A. (red.). 2015. Obyczaje w Polsce. Od średniowiecza do czasów wspótczesnych. Warszawa Wydawnictwo Naukowe PWN.

Corbin, A. (red.). 2013. Historia ciała. Od Rewolucji do I wojny światowej. Tom II. Gdańsk: Wydawnictwo słowo/obraz terytoria. 
Courtine, J.-J. (red.). 2014. Historia ciała. Różne spojrzenia. Wiek XX. Tom III. Gdańsk: Wydawnictwo słowo/obraz terytoria.

Eco, U. (red.). 2007. Historia brzydoty. (przeł. Justyna Czaplińska i in.). Poznań: Rebis.

Eco, U. (red.). 2005. Historia piękna. (przeł. Agnieszka Kuciak). Poznań: Rebis.

Eco, U. 1994. Sztuka i piękno w średniowieczu. (przeł. Mikołaj Olszewski) Kraków: ZNAK.

Etcoff, N. 2000. Przetrwają najpiękniejsi. (przeł. Dominika Cieśla) Warszawa: CIS, WAB.

Gołaszewska, M. 1984. Estetyka rzeczywistości. Warszawa: Wydawnictwo Naukowe PWN.

Jakubowska, H. 2009. Socjologia ciata. Poznań: Wydawnictwo Naukowe UAM.

Karwatowska, M., Litwiński R. i A. Siwiec (red.) 2014. O ptci, ciele i seksualności w kulturze i historii. Lublin: UMCS.

Karwatowska, M., Litwiński, R., Siwiec, A. i B. Jarosz (red.). 2014. O ptci, ciele i seksualności w języku mediów. Lublin: UMCS.

Kostrzewa, M. 2014. „Kreowanie wizerunku kobiety w kontekście zmieniającej się mody, preferencji estetycznych i poszukiwań twórczych projektantów w przestrzeni wybranych kultur". W zbiorze: Wojnowska-Radzińska, J. (red.). Kobieta i płeć w dyskursie aksjonormatywnym. Kalisz: Wydział Pedagogiczno-Artystyczny UAM. 119-138.

Kostrzewa, M. 2016a. „Rola ubioru jako elementu twórczej ekspresji i narzędzia komunikacji niewerbalnej we współczesnym świecie”. W zbiorze: Łuszczykiewicz, P., Kowalczyk, B. i M. ZdrowickaWawrzyniak (red.). Medialny obraz rzeczywistości. Poznań: Wydawnictwo Naukowe „Silva Rerum" we współpracy z Wydziałem Pedagogiczno-Artystycznym UAM w Kaliszu. 203-226.

Kostrzewa, M. 2016b. „Kreowanie wizerunku kobiety z uwzględnieniem relacji mody i ciała”. W zbiorze: Romecka, S., Gałkowski, A. i A. Grudzińska-Pham (red.). Piękno i brzydota w ujęciu artystycznym i humanistycznym. Łódź: Wydawnictwo ASP im. Wł. Strzemińskiego w Łodzi. 146-147.

Kostrzewa, M. 2016c. „Eksperymenty twórcze wokół sztuki, mody, edukacji i ich rola w budowaniu tożsamości artystycznej środowiska akademickiego w Kaliszu". W zbiorze: Kowalska, S. (red.). Dziedzictwo kulturowe miasta Kalisza i regionu Południowej Wielkopolski. Tom V. Poznań/Kalisz: Wydział Pedagogiczno-Artystyczny UAM. 103-143.

Kostrzewa, M.I. 2016d. Sea grey - creative adaptations / Sea grey - twórcze adaptacje. Kalisz: Wydział Pedagogiczno-Artystyczny UAM.

Łaciak, B. (red.). 2014. Obyczajowość polska początku XXI wieku - w procesie przemian. Warszawa: Wydawnictwo Akademickie Żak.

Morris, D. 2000. Naga matpa. Warszawa: Wiedza Powszechna.

Pełka, A. (red.). 2013. Z (politycznym) fasonem. Moda młodzieżowa w PRL i NRD. Gdańsk: słowo/obraz terytoria.

Simmel, G. 2006. Drzwi i mosty. Wybór esejów. Warszawa: Oficyna Naukowa.

Szpakowska, M. 2008. Antropologia ciała. Zagadnienia i wybór tekstów. Wiedza o kulturze. Część IV. Warszawa: WUM.

Vigarello, G. (red.). 2011. Historia ciała. Od Renesansu do Oświecenia. Tom 1. Gdańsk: słowo/obraz terytoria.

Worsley, H. 2001. 100 idei które zmienity modę. (przeł. Małgorzata Dera). Warszawa: TMC.

Yalom, M. 2012. Historia kobiecych piersi. Łódź: Instytut Psychologii Zdrowia PTP.

Zalewska, J. i M. Cobel-Tokarska (red.). 2014. Od obyczaju do mody. Przemiany życia codziennego. Warszawa: ASP.

Ziółkowska, B., Cwojdzińska, A. i M. Chołody (red.). 2009. Ciało w kulturze i nauce. Warszawa: Wydawnictwo Naukowe Scholar. 